\title{
Registration and credit in seventeenth-century England
}

\author{
SEIICHIRO ITO \\ Ohtsuki City College
}

The English law reform movement produced numerous proposals for land registries during the Interregnum, but the idea of land registration took on economic connotations only after the Restoration, when controversy arose over the role of registration as a settled and reliable basis of credit. While the discourse of law reform was confined to the context of English law, the debate over whether and how land registries should be established extended to the economic field, and to international arenas in which England competed with, and sometimes imitated, her rivals in trade, particularly Holland. On one side of the debate, advocates of land registration insisted that registries would clarify the ownership of land, offer a firm foundation for credit, and consequently, improve English trade. On the other side, opponents of registration argued that such excessive openness of information would be hazardous to credit. For both advocates and opponents alike, the central issue was the role of registration in creating more reliable credit.

Keywords: registration, land bank, law reform, seventeenth century

JEL classification: $\mathrm{N}_{23}$, B I I

In his bank proposal of I678, Mark Lewis reasons, 'Registers will make Security, Security will bring mony', and hence, registers will 'bring mony' (Lewis I678, p. 33 [32]). Lewis's syllogism was a compelling one for seventeenth-century pamphleteers on trade and credit in England, though to us the relationship between registers and money may seem obscure. ${ }^{1}$ During the seventeenth century, particularly in the latter half, proposals for banks in England centred on the notion that a 'fund', or security, whether consisting of cash, goods, or land, was a crucial, foundational element of a bank. Bank proposers of the period would naturally assume that registration of the

Seiichiro Ito, Department of Economics, Ohtsuki City College, 1-16-2 Mitachi, Otsuki-shi, Yamanashi 401-0012, Japan, seiichiro@mtj.biglobe.ne.jp. Earlier versions of this article were presented at the 12th Annual Conference of the European Society for the History of Economic Thought, Prague, in May 2008 and at the 22th Conference of the History of Economic Thought Society of Australia, Fremantle, in July 2009. I am grateful to two anonymous referees for their helpful comments. The Japan Society for the Promotion of Science (JSPS) provided financial support for this research, for which I am also grateful.

${ }^{1}$ Sheppard and Belcher (I980) offer some discussion, if not as their main subject, of the close relationship between credit and the registration of estates in the seventeenth century. 
contents of a bank's security would be a necessary and useful measure for improving the quality of credit offered by that bank.

An understanding of why bank proposers would make this assumption begins with the 'want of money' that haunted the people of seventeenth-century England. ${ }^{2}$ The struggle to overcome this want was marked by the transition, as Wennerlind (20 I I) describes it, from the neo-Aristotelian view of a finite world, in which the use of metal money restricted trade, to the Hartlibian perspective of infinite expansion, in which credit would remove that limit. Throughout this transition, the English nation and its trade swayed in the political and religious turbulence of the shifting balance of power in Europe (Pincus I996, 2009). Amsterdam and London were emerging as the two main centres of European finance, the latter having a competitive advantage as an eager borrower of Continental ideas, in that in international financial market technical 'innovations can become more productive when they are transplanted' (Carlos and Neal 20 I I, p. 23; also see Neal I990, p. Io). In the English political economy prior to 'the first modern revolution' of I 688, a contest was unfolding between the tory-agrarian economic view, in which the nation's wealth, dependent on the land, is finite, and the whig-commercial view, in which wealth originates with labour, and is therefore infinite (Pincus 2009).

It was also the case that throughout the seventeenth century, the English economy had been plagued by a systematic uncertainty. The credit available for trade was generally insecure and unreliable. Muldrew (I998) describes a weak if widely extended non-institutional credit network in sixteenth- and seventeenth-century England which was based on socio-moral factors such as reputation and trust. ${ }^{3}$ As Muldrew explains through the lens of Hobbes, 'people [of the period] would not extend trust unless they were confident that the authority of the law was present' (Muldrew I998, p. 322). Glaisyer (2006) observes a credit system operating also on a socio-moral basis in the Royal Exchange of London of the seventeenth and eighteenth centuries (pp. 38-42). Ito (2OII) characterises the discourse of banking in seventeenth-century England as a search for the best form of security to serve as a foundation for the unfamiliar institution of credit.

Against this background, the idea emerged among contemporary bank proposers that the registration of estates would help make credit more trustworthy and reliable. Yet the idea was a controversial one; prolonged debate over the establishment of registries, in which the function of registration to build a more certain credit system was at issue, continued through the latter half of the seventeenth century.

In this article, I offer, first, a survey of the issues and vocabulary of the legal discourse of the law reform movement of the Interregnum, which would remain central in the

2 See Heckscher (I935); Horsefield (I960); Kerridge (I988); Richard (I965 [I929]); Supple (I957).

3 McGowen (2002) questions Muldrew's 'central contention that the many thousands of credit transactions were all the same' (p. I29), and Hill (2007) sees in the 'narrative representations' in the Court of Requests that the maintenance of the credit network was more complicated than Muldrew describes (pp. I36-56). 
debates over registration after the Restoration. I then turn to post-Restoration public discussion of the registration of estates, focusing on contemporary understandings of the relationship between registration and credit. As this discourse reveals, the pamphleteers of the time, understanding the availability of credit to be a prerequisite for improving trade, supposed that credit could only arise on a firm foundation, and viewed registration as a leading candidate to play that role.

English law during the time of Elizabeth I and the early Stuarts was in a state of transition. The traditional legal order had to be adapted to new conditions and problems (Brooks 2008, p. 430). Within the existing legal order in England, in which common law and Roman law functioned in parallel, and often competed, the recording, authorising and registration of written documents within the Roman law tradition had become a source of conflict (Brooks 2008, p. 308; Brooks, Helmholz and Stein I99I, chapter I). Although notaries public who recorded and authorised documents had long been an institution in England, the documents produced by the notaries in cases concerning deeds and conveyances of land, for example, were not necessarily used in litigation as a fixed routine; this suggests that existing institutions did not function systematically, or that the system was not trusted. Forgery and fraud, which public notaries could not prevent, was attributed by contemporary writers to the lack of an authorised registry (Brooks, Helmholz and Stein I99I, pp. 38, IOI-7). It was in this context of law and society that the law reform movement adopted the registration of estates as a major issue.

Spurred by substantial discussion of the Common Law by Edward Coke, Francis Bacon and John Lilburne, and encouraged by the formation of a new government in I649, the law reform movement generally sought remedies for the 'slow, expensive, and arbitrary' judicial processes of the Court, ${ }^{4}$ but most of the reformists' pamphlets included proposals, whether in passing or in detail, for registration (Veall I970, p. 56; chapter 3; pp. 219-24). The reformers agreed on the necessity of keeping records, yet their views varied on how these records should be maintained.

The reformers also shared a common understanding of the purpose of registration, namely, that it might serve to protect against fraudulent deeds and conveyances. Frequently, expressions of this view provoked fears that registration would bring about the exposure of concealed contracts, leading to an increase in the number of

4 Shapiro (I975) argues that the major concerns of the law reform movement during the Interregnum, including 'the expense, complexity and lengthiness of lawsuits', 'had all come under the scrutiny of parliamentary reformers before I640' (p. 288). Pocock (I987 [I957]) traces the constitutional discussion of common law and feudal law in Burkean terms. Some of the major figures in his book, such as Matthew Hale and Edward Coke, participated in the law reform debate, although this is not Pocock's interest. Cotterell (I968) portrays the Hale commission as moderate in character. 
lawsuits along with their associated costs. ${ }^{5}$ Such fears certainly included trepidation about the existence of the undetected estates; during the reigns of Elizabeth I and the early Stuarts such 'concealed lands' were supposed to offer 'the best and richest source of fresh revenue' and the assiduousness of the searches for such lands left bitter memories (Thirsk I992, pp. 30I, 346-7). Nonetheless, throughout the booms in law reform pamphleteering at the inception of the new government and in I65 I, I653 and I659, issues surrounding the protective function of registration continued to frame discussion of the subject.

Hugh Peters, a loyalist of Cromwell and a social reformer, ${ }^{6}$ thought the remedy for confusion in the law lay in 'keeping Records in all Counties of all mens estates and alienations, \&c. and those transmitted to a grand or leiger [sic] Record at Westminst[er]' (Peters [I647], p. I3). At the end of the preface of his pamphlet of 7 July I65 I, half a year before he was named a member of the Hale commission, ${ }^{7}$ Peters set forth the establishment of registers as the first of the 2I proposals in his 'short Model for the Law'. Peters proposed 'Registers to bee settled in everie Parish, kept every year by two men chosen to that work; and all Lands and houses entred into that book distinctly; and the Copie thereof transferred to the Countie-Town, in case of fire, \&c. and in these books all alienations \&c. entred' (P[eters] I65I, pp. 27-8).

Others pursued similar arguments. An anonymous pamphleteer, arguing for the necessity of preventing the 'defrauding and defeating of Creditors', proposed appointing commissioners in each county 'for the acknowledging of all sales, Bargains, contracts, and conveyances, \&c.', which would be registered alphabetically in a public book (Anonymous I649, p. I9). Another anonymous pamphleteer argued for erecting 'a publique Register' in every county to register the same sorts of transactions of property; this author also intended these measures to prevent fraud and lawsuits (Anonymous [I650], p. [I]). William Leach, an attorney who was himself frequently in debt, ${ }^{8}$ similarly aimed in his proposals to prevent 'great numbers of secret, fraudulent Deeds and Conveyances, and other frauds and deceits', which he viewed as causes of costly lawsuits and other problems. The remedy, according to Leach, was the registration in each region of all details of transactions bearing on property rights (Leach I65I, pp. 2-3).

5 Concerning the incidence of litigation over debts and contracts in the seventeenth century, see Muldrew (I998, chapter 8).

${ }^{6}$ See 'Peters, Hugh', British Radicals, vol. 3, pp. 30-2; ODNB; Slack (I998, pp. 78ff). Peters is a major figure in Robert Brenner's story of 'the new merchants'. See Brenner (I993, particularly chapters IO and I I). According to Cotterell, Peters was one of 'the hard core of the radical minority' of the Hale commission (Cotterell i968, p. 692).

7 When the commission was appointed on 26 December I65 I, Peters's name was not on the list of 'fit Persons'. His name first appears on the list of 9 January I652. See CJ, vol. 7, pp. 58, 67.

8 See 'Leach, William', British Radicals, vol. 2, pp. I80-I; ODNB. 'Mr Leech' is on the list of the appointed member of the Hale commission of 9 January I652 of House of Commons Journal. CJ, vol. 7 , p. 67. 
Henry Robinson, ${ }^{9}$ a social reformer (rather than a law reformer) who was associated with Samuel Hartlib's circle, was also concerned with this issue. He directed his proposals at the problems of 'superfluous Offices', 'unnecessary Fees', and 'the Multiplicity of Courts of Justice'. To reduce and prevent lawsuits, he proposed establishing a 'County Register' of conveyances, bonds and bills of debt. Robinson realised, as did Benjamin Worsely, another Hartlibian, that power and wealth are inseparable and that therefore the government needed to supervise certain aspects of commerce. ${ }^{10}$ From this perspective he suggested that registration would 'exceedingly facilitate and enlarge Trade and Navigation' (Robinson I65 I, pp. -6--2).

The reformist pamphlets published by i65 I thus shared some common elements, including the establishment of a registry in each region to prevent fraudulent dealings in estates and costly lawsuits. All advocated registration as part of law reform.

The Hale commission was set up to consider law reform in the context of this discourse, though in character the commission proved rather moderate; Matthew Hale himself used his influence 'in a conservative direction' (ODNB, vol. 24, p. 535). ${ }^{11}$ During May and June of I652 the commission held intensive discussions on registration. Of the ten meetings of the commission between I2 May and 7 June, Hale participated in five, and Peters seven (Minutes, fos. 17-82). Discussion during these meetings ranged widely and delved at times into great detail, but the issues considered were generally the same as those addressed in the pamphlets discussed above, such as whether a public registry should be set up in every county or there should be only one general registry in London; what should be registered; and how to deal with the concealment of estates (Minutes, fos. 72, 76, 73ff., 81, 82).

Subsequent to these meetings of the Hale Commission, the debate among pamphleteers on the registration of estates reframed the issue around new vocabulary and concerns. In I653, the following year, a pamphleteer identified as J.F. proposed registration in every shire of 'all Leases, Bargains, Conveyances, Statutes, Judgements, [and] Recognizances' concerning land (J.F. I653, p. 5). However, others had doubts about the effects of registration. The anonymous author of a pamphlet entitled Reasons against the Bill, intituled, An Act for Countie-Registers, Wills and Administrations warned that, if all deeds had to be registered, numerous people would be 'made guiltie of undoing themselvs [sic]; being made to discover the flaws in the Titles to their estates'. Then the commonwealth would be swarmed with 'Informers, Prowlers, and searchers unto other men's Titles' and, at last, would cause an increase in the number of lawsuits (Anonymous I653, pp. 7-8). Similarly, the author of an

9 See 'Robinson, Henry', British Radicals, vol. 3, pp. IOI-3. Regarding his bank proposal, see Robinson (I652).

10 See Leng (2005, p. 94I; 2008, p. 6I).

11 According to Cromartie, 'Hale chaired the first two meetings, but there after became an irregular attender' $(O D N B$, vol. 24, p. 535). However, the minutes of the committee show that Hale chaired the first eleven meetings, from 30 January to 23 February, and that he attended subsequent meetings diligently. See Minutes of the Extra-Parliamentary Committee for Regulating the Law. 
anonymous manuscript filed in The Hartlib Papers worried that registers 'may Constraine men to discover the Flawes in their titles'. To preclude this possibility, this author proposed that if claims on estates were not challenged within six months, they be granted and recognised thereafter. The author argued that this procedure would prevent lawsuits. He furthermore wondered why such registration might not be practised in England, 'as well as in Holland' (Anonymous n.d., 66/16/4B, 3A, 4B), whose social system was the ideal model for the English. 'J.W.', another reformer, thought that wills, inventories, rentals and lands should be registered such that an inheritance 'may not be wronged, nor creditors defrauded.' However, he added a caution about public access to registered information: the contents of registries were 'to be kept secret from all persons' but those concerned with the registered property (J.W. I653, p. I2). Beyond the question of regional registration and the aims of preventing fraudulent dealings and reducing lawsuits, such concerns about the dangers of public scrutiny of estates would remain at issue through generations of debate over registration and credit to follow.

In I657, William Sheppard, whose magnum opus, England's Balm, represented 'a comprehensive plan that resolved all the complaints' about law (Matthews I984, p. 4; also see $O D N B$ ), proposed county registries as the solution to the problems caused by the ambiguity of property rights. Sheppard proposed that records of fines, deeds and bonds or bills above one hundred pounds should be sent to 'the County-Registry'; that all recognisances should be sent and endorsed there; and that such a registry should be erected in every county (Sheppard I657, pp. II2, II3-I4, I2I).

The last wave of debate over registration in the context of the law reform movement crested in the closing period of the Commonwealth a few years later. A series of proposals written in I659 pursued the same topics and arguments as before. Edward Billing argued that 'Courts of Record' should be set up in each county, to record as many types of articles as possible (Billing I659, p. 3). William Sprigg, who took part in the Baconian experimental philosophy circle at Oxford and was influenced by James Harrington, ${ }^{12}$ also supported registration in each county, viewing it as commended both by 'the general suffrage of all men' and by lawyers themselves ${ }^{13}$ as 'an admiral expedient for preventing frauds and securing of Inheritances' (Sprigg I659, p. 73).

In contrast to the proposals for registration we have considered thus far, which for the most part appeared as briefly described elements of broad law reform projects, registration played a fundamental role in a proposal by a writer identified as 'Wellwiller'. In the six-day work the writer proposed to create a world out of 'Chaos', he assigned the second day to prescribing 'the Rules for Registers'. His proposal was institutional and detailed; he called for the establishment of a 'National Register' at Westminster, 'a Provincial Register' in each shire-town, a 'Sub-provincial

12 See 'Sprigge, William', British Radicals, vol. 3, pp. 196-7; ODNB.

13 According to Veall (I970), most lawyers opposed law reform, because they 'saw it as a threat to their privileged monopoly position' (p. 229). 
Register' in each sub-province, and a 'Parochial Register' in each parish. Each of these should have clerks, assistant, and deputies, and each should maintain its own seal (Anonymous I659a, pp. 6-I4). The items that 'Well-willer' viewed as requiring registration ranged widely; the list included not only rights, titles, estates, debts, bargains and contracts, but also children having estates, marriages, the births of children, christenings, deaths and burials, wills and testaments, and servants (Anonymous I659a, pp. 9, I7-I 8). 'Well-willer' furthermore strictly prescribed the fees for registering these items. These works of the second day of creation established a framework for the tasks of the rest of the week, which included the ordering of judicial procedures, parliamentary elections, the raising of public revenue, workhouses for the poor, commerce and education.

As calls for registration continued to mount, the most commonly stated purpose remained the reduction of strife and lawsuits. The anonymous author of The Honest Design insisted on complete registration of estates such as houses and lands in order to 'end all Suits' (Anonymous I659b, p. 3). William Cole ${ }^{14}$ shared the same idea: if all laws, leases and mortgages were registered, he argued, 'all old suits' would be ended (Cole I659, p. I2). Yet a pamphlet entitled $A$ Treatise Shewing how Usefull, Safe, Reasonable, and Beneficial the Inrolling \& Registring of all Conveyances of Lands May Be to the Inhabitants of this Kingdom, which has been attributed to Matthew Hale, ${ }^{15}$ raised concerns about registration that anticipated the debates that would arise after the Restoration. At the beginning of this pamphlet, the author identified two 'Mischiefs at present': firstly, deceits caused by 'secret' judgements, mortgages, conveyances and settlements; and secondly, a large number of tiresome lawsuits resulting from these deceits. Although the author's remedy to these 'Mischiefs' was 'an Office of Inrollment, or Registry of Conveyances', he recognised problems with such an approach. Firstly, he acknowledged that if any estates are not registered and are in 'some way rendred open to the view of every Person, a Man may be cheated or deceived', leading to more lawsuits, and therefore he cautioned that registration must be completely thorough. In brief, registration might create excessive exposure of information and lead to the multiplication of lawsuits (Hale I694, pp. I, 4, 7, I3). The author's cautious view of registration may be attributable to his politically 'conservative stand' (Cromartie I995, p. 72). Nonetheless, it prefigured the concerns about registration that would arise again and again in the debates following the Restoration.

Most of the law reformers who advocated registration did so within a legal or judicial framework, rather than in relation to credit. Following the Restoration, however,

14 See British Radicals, vol. I, pp. I59-60; ODNB.

15 Veall (I970) is suspicious about the authorship of this pamphlet (p. 223). Cromartie (I995) notes, ' $[\mathrm{t}]$ he authenticity of this pamphlet has been doubted, but its manner is highly characteristic' (p. 72n). 
Francis Cradock tried to connect registration and credit. Soon after Cradock's appointment for life to the office of Provost Marshal General of Barbadoes (on 2 August I660) (CSPC AWI, vol.I, no. 33), he presented his general ideas on banking in a pamphlet dated 25 April I66I. Cradock characterised his model of a land bank as an extension of previous discussions. He had pursued the directions indicated by the 'compass' of his 'own Library', which included Malynes's Lex Mercatoria, Lewis Roberts's Mappe of Commerce, Henry Robinson's Trade Encrease in England's Safety and Samuel Lamb's Seasonable Observations. In these works, Cradock found 'an Encouragement' to 'imitate' the cases of other countries, such as Holland, Genoa and Florence. However, in contrast to foreign examples of 'Banks of Money', the bank Cradock proposed was to be 'erected without Money', a difference that Cradock offered as an improvement or extension of previous models, rather than merely an imitation. Indeed, Cradock viewed his plan as originating in William Potter's 'hints of a Land-bank', which itself went well beyond the imitation of foreign examples (Cradock I66I, p. -2). ${ }^{16}$

Cradock's argument proceeds methodically. First, he defines a bank as a corporation for keeping cash, making payment by assignment, and transferring the ownership of money, as was the 'daily practice in the Low Countreys'. Cradock then poses a question: why could there not be a bank in which not only 'Money coyned', but also 'Wedges and Vessels of Gold or Silver', were kept? Such banks were commonplace in Holland. Cradock next asks, why not 'other Merchandize' such as linen, draperies, silks, iron, sugar, wine, tobacco and fruit? The idea of banks which would offer credit on the security of goods, i.e., so-called Lombard banks, was familiar in England during this period, but Cradock went further, reasoning that 'Lands may be as good, if not better security then Money or Jewels' (Cradock I66I, pp. 4-7).

Cradock argued that a bank whose security was land could be a remedy for various 'inconveniences', such as lack of sufficient silver and gold, the danger of carrying cash, loss of time spent counting, and the hazards of receiving clipped money. Registration played an essential role in Cradock's orderly explanation of how a land bank would function: he proposed that England be divided into a hundred divisions, 'a standing and constant Bank or Registry' be erected in each precinct, all estates and their rents be registered there, and a method of keeping those registries be agreed upon. Cradock asserts that if these measures are taken, banks 'wherein real security by Land may be a foundation of Credit' would function effectively (Cradock I66I, pp. 7, I0, I4).

Cradock acknowledged that in parliament, registration was a controversial matter, noting that 'the alone subject of a Register has been formerly debated'. Opponents might have viewed registration as an impediment to land bank projects based on it because of the risk it posed of the discovery of concealed estates. Cradock addressed this concern with his claim that with registration, lawsuits concerning the titles of estates 'will in a short time be ended' and, furthermore, that 'no man will be

16 Concerning the bank proposals mentioned here, see Horsefield (I960); Ito (20 I I); Wennerlind (20 I I, chapter 3). 
obliged to discover his Conveyances or to shew them at the Banks' (Cradock I66I, pp. 32, 27, 29, 32). However, Cradock also expressed doubts about the feasibility of registering all estates and encumbrances. Notably, the issues with which Cradock dealt had all been raised in legal debates during the Interregnum, and he was aware of this in framing his proposal for a land bank in a way that integrated two discourses that had been distinct, that of bank proposals and that of law reform. Cradock's proposal offered a novel approach to registration and credit which anticipated subsequent debates.

On I9 November of I66I, Cradock petitioned the king for the authority to establish a bank 'without money' in Barbados, because 'no experiment' of such a bank had been made in England. Lord Ashley reported, on 3 December, that he had 'no confidence in the success of the first experiment of new inventions, especially in matters of this nature'. In Ashley's view, the prospect of a bank without money would seem almost as 'great a mystery' as 'a novelty'. '[W]ithout a precedent', Ashley reasoned, it would hardly be possible to 'gain credit with a people', and therefore, the 'experiment' in Barbados would be an indispensable step towards the establishment of such banks in the future. When a bill authorising this project was warranted on 9 December, it was prepared on the basis of Cradock's pamphlet. Not only would the bank be 'founded on the security of lands and goods', but '[t] he office of keeping the records of estates' was also 'to be kept at the banks'. Soon after, in March of I662, Cradock was empowered to establish banks, but it is not clear whether he did so or not. In either case, an objection raised to making Cradock's tenure as Provost Marshal lifelong suggests that the experiment was unsuccessful. Cradock died around August of I667 (CSPC AWI, vol. 5, nos. I83, I 83 II, I 83 III, I94, 265, 266, 696, 759, 759 I, 759 II, I 555).

The relationship between credit and registration that Cradock made explicit appears to have come to the attention of other pamphleteers by around I660, though often they addressed it only in notes and hints. For instance, William Petty, a Baconian social reformer who gathered demographic information on Ireland, ${ }^{17}$ briefly referred to credit and registration in his Treatise of Taxes \& Contributions in I662, but did not explain how they related to one another in any detail. Petty's interest was clearly in the potential effects of registration on the incidence of lawsuits, rather than on credit (Petty I 899, pp. 26-7).

Petty also referred to registration, credit and legal issues in his 'Proposalls concerning the Registry in Ireland', which he wrote in I66I, offering a somewhat clearer sense of the connections between them. As he explained in this manuscript, if the values, titles and deeds of estates were recorded at registries, land would become 'a Bank of money, which is farr more safe and commodious than coynes', and registration would reduce the lawsuits in Ireland by half (Petty I927, vol. I, p. 78). ${ }^{18}$

17 See McCormick (2009, p. I 26). According to McCormick, Petty regarded registries as 'a tool of scientific government' (p. I27).

18 McCormick (2009) observes that '[i]n his letter to Ormond, Petty had offered a proposal for a registry' which may have come from Hartlibian projects (p. 280). 
However, although Petty was undoubtedly aware of the law reform debates discussed above, the effect of registration on credit was not his major concern.

Nonetheless, the connection between registration and credit was widely recognised among pamphleteers of this period, particularly those belonging to the socalled Hartlib circle. Samuel Hartlib was a German Calvinist immigrant 'committed to the advancement of knowledge through the promotion of communication and intellectual exchange' (Leng 2008, xii). His circle represents an important step in the institutionalisation of the Baconian project of science, which would culminate in the establishment of the Royal Society of London after the Restoration (Hunter I98 I, I989). Petty, a member of the circle, applied alchemical ideas to the solution to the demographic problem in Ireland, arguing for 'the transmutation of the Irish into English, the transmutation of costly idlers into industrious workers' (McCormick 2009, p. 207). Moreover, according to Wennerlind (20I I, chapter 2), the Hartlibians also drew on alchemical thinking in their efforts to solve the problem of want of money. Pursuing a 'universal reform and infinite improvement project', the Hartlib circle discovered their 'philosopher's stone' in credit, which they viewed as offering infinite potential (Wennerlind 20II, pp. 46, 55). Credit thus became an integral topic in discussion of Hartlibian social reform projects, and registration played a significant role in the discourse on this topic.

An undated handwritten memorandum by [Samuel] $\mathrm{H}$ [artlib] in The Hartlib Papers provides an example of the combination of elements - the Dutch model, security and registration - that proposals concerning institutional credit typically comprised in the mid-seventeenth century. First, the memo introduced successful new credit systems from the Continent: in Flanders, bills and bonds circulated; and in Holland, specie was brought to the Bank of Amsterdam, and based on this 'securitie', there followed 'a continuall assignation (from hand to hand) of the ownership (onely) of the money which lay in the Bank'. From the examples of the 'long experince [sic]' of Flanders and Holland, Hartlib reasons, it is obvious, firstly, that credit does fully 'supply the office \& place of money'; secondly, that it is preferred to money because it is 'easier, qvicker \& safer' than payments by money; and thirdly, that the credit system in these two cases is fragile, in that it was 'settled vpon noe better foundation, then either the personal security of one man, or (in Holland) vpon a meere supposition, that such a summ is lying in the Bank, as will fully answer the Capitall that should be there'. Hartlib then suggests that there is 'a way of registring of Lands' which leads to 'the least trouble \& charge' and such security would offer a sound basis for borrowing (The Hartlib Papers, [27/I4/IA-IB]).

Another undated memorandum from The Hartlib Papers proposed not only the establishment of 'compting houses' where payments would be made by bills of exchanges, but also 'a howse of Commutation of all kinde of Commodities or Wares', managed 'by Register kept thereof. This institution, according to the author of this unsigned memorandum, would bring benefits and 'Commodiousnes' for trade: it would not be subject to the danger accompanying the transportation of money; it would prevent lawsuits on bills of exchange; and it would reduce 
trafficking in stolen items, in that ' $[\mathrm{m}]$ ost stollen goods shall bee hereby detected and theevery doth decrease by the true Register and Tickets given and kept thereof (The Hartlib Papers, [66/I9/IA; IB; 2B]).

\section{III}

Sir John Nisbet of Dirleton, Lord Advocate of Scotland, advocated land registration in England, suggesting that if it were set up along the same lines as the system already established in Scotland, ${ }^{19}$ with 'all Writs appointed to be Registred concerneing lands, within a certaine precinct of bounds', then many of the problems surrounding purchases of land would thereafter be avoided (Nisbet of Dirleton [I669], fo. I64). Beyond Nisbet's views a series of reports from 'the Committee for considering the Decay of Trade, Fall of Rents, \&c.' in the House of Lords during the winter of I669-70 elicited a number of pamphlets concerning registration, all of which dealt with economic issues. ${ }^{20}$ On 24 November I669, in the House of Lords, the Earl of Essex, a member of the committee, reported that 'the Lords Committees do think fit to offer to the Consideration of this House Three Things'. The three items to be considered were 'Interest of Money', 'Registers for Estates', and 'Naturalization'. On the second topic, the earl commented that one reason for the decline of rents and land values is 'the Uncertainty of Titles of Estates'; he then suggested that 'a Bill of Registers' should be introduced (LJ, vol. I2, p. 274). Thus, the economic situation was bad enough that 'the Committee for considering the Decay of Trade, Fall of Rents' had been named, and remedies for high interest rates, uncertainty surrounding titles, and want of people were high priorities. Registration of estates was clearly mentioned here as such an economic remedy. Hence, though some issues from the field of justice, such as reducing lawsuits and preventing fraud, had been discussed in numerous pamphlets on registration for more than a decade, ensuing discussion focused on economic matters.

Outside parliament, debate associating registration and credit was undoubtedly motivated by and based on the original version of Fabian Philipps's The Reforming Registry, which appeared in I662. Philipps, who was 'in favour of the authority of the monarch', ${ }^{21}$ made the assertion that ' $\left.\mathrm{t}\right]$ he erecting of Offices for the Registring of Deeds and Conveyances Indented in every County' would be 'needless'. The full title of the pamphlet tells that it was originally written in 1656 , and that during the Interregnum, Philipps (I662) opposed the law reformers, who were generally in

19 Concerning the registration system of Scotland in the seventeenth century, see Hoppit (2003, pp. $92-3)$.

20 According to Garnier, the English were confronting increasing intricacies in transfers of land and obscurity in the processes of seisin and enfeoffment in the I66os; '[n]o wonder, then, that we find in the writings of this age frequent attempts to revert back to forms of public registry, which had so simplified alienations in primitive times' (Garnier I908, vol. II, p. 96).

21 ODNB, which does not refer to Philipps's writings concerning registration. Pocock (I987) describes Philipps as a kind of 'Filmerian' (pp. 2I5-I7). 
favour of registration. ${ }^{22}$ Philipps was against establishing registries in every county for the following reasons: records would be 'illiterately, carelesly, and ill-favoredly' registered; in times of trouble they would not be so 'safely kept' as they would in London; and an 'inforcement' to register all deeds in counties would diminish 'the Common Right and Liberty' (Philipps I662, pp. 3, 4, 8, I4-I 5, I9).

Forgery and counterfeiting, the main obstacles to smooth economic transactions in this century, ${ }^{23}$ also provided Philipps with reasons for opposing registration. Deeds to be registered, he argued, could easily be 'forged, counterfeited, or antidated', and would produce more 'deceits and incumbrances, then they do pretend to prevent'. It followed for Philipps that registration would precipitate an increase in lawsuits informers, a consequence that figured centrally in arguments throughout the history of these debates, as we have seen (Philipps I662, pp. 29, 47).

The most serious, and above all, economically critical problem resulting from registration, in Philipps's view, was its potential for causing a crisis of credit. If bonds and bills had to be registered, he asserts, it would 'too much discover every mans Estate, and double every mans misery and wants, in taking away his credit' (Philipps I662, pp. 58-9). In the event that registries are established, Philipps worries, tradesmen and merchants 'who live upon credit, diligence and industry, ... will be so laid open to the view and jealousie of their Friends and Creditors, or such as they trade with, as they will every one be so afraid of the poor Debtors'. In Philipps's view, nobody would lend anything to 'a yong hopful Tradesman', whom all would know lacked sufficient means to secure the trust of creditors (Philipps I662, pp. 60-I; I67I, pp. $64-5) .{ }^{24}$ The relentless exposure of debtors' information thus would have fatal consequences in a credit-based economy, and all the more so in one in which that credit was fragile and uncertain. ${ }^{25}$ Philipps's fear here extends far beyond that observed by Thirsk (I992) - the fear in early Stuart England that concealed estates might be

22 The full title is The Reforming Registry, or, A representation of the very many mischiefs and inconveniences which will unavoidably happen by the needless, chargeable, and destructive way of registries: proposed to be erected in every county of England and Wales for the recording of all deeds, evidences, bonds, bills, and other incumbrances: written in the yea[r 1]656 when Oliver and the Level[l]ing party made it their design to ruine monarchy, the laws of the nation, and the impoverished Loyal Party.

23 In seventeenth-century England, clipping and counterfeiting of metal coins were acts of treason, but nonetheless, clipping and counterfeiting businesses were widespread. See Gaskill (2000, chapters 4 and 5). Kleer (2004) shows that the primary motive for the recoinage of I695 was to curtail clipping and counterfeiting of coin. Wennerlind (20 I I, chapter 4) demonstrates that the integrity of coin was essential for the survival of the Bank of England, and eventually, the post-Glorious Revolution government. Forgery and counterfeiting of documents concerning estates were similar problems in a time inundated with scepticism.

24 In I668, a pamphleteer argued that the reduction of the interest rate by law would make it difficult for industrious and ingenious young men to borrow money for new businesses. See H.R. (I668).

25 Philipps, considering how to prevent frauds, deceits, and concealments 'in the king's customes', argues that the 'Imventary Invoyce cargazon or Bill of Ladeing' should be 'registred entered examined and compared with the cocquett or note of Goods and wares' (Philippe [= Philipps] I665, fo. I27). 
discovered and taxed; rather, it responds to a threat to the socio-moral order of credit as a whole.

\section{IV}

Philipps's concerns about the negative effects of excessive information on the credit system would remain a contentious issue in subsequent discussion. In I669 an anonymous pamphlet appeared entitled, A Seasonable Proposal to the Nation Concerning a Register of Estates in this Kingdom: tendred to the consideration of the publick-spirited in both houses. As the title clearly shows, the pamphlet was a response to the discussion in parliament. A Seasonable Proposal envisioned 'a Register of Estates' as '[t]he Grand thing worthy the design of every Publick-Spirit' which 'should bring all Possessions of Houses and Lands to one Tenure', and offered as the principal reason for its establishment the need to reduce the incidence of lawsuits. In contrast to Philipps, who asserted that a register would multiply the number of lawsuits, the author of $A$ Seasonable Proposal argued that registration, 'at one dash', would make an end to contention, including lawsuits, concerning the titles of estates. Casting a dubious eye at opponents of registration such as Philipps, the author argued that the true motivation of lawyers who profited from suits was the concern that with registration, 'men are not like to go to Law as they now do', that is, that registration would reduce the earnings of lawyers (Anonymous I669, p. 3).

Another argument that $A$ Seasonable Proposal offers against registration is clearly directed at Philipps in particular. 'The Broken-Tradesman', the author suggested, 'likewise will exclaim; This will hinder Trade; many now live on their Credit, but when the Register shall tell all, they shall not be trusted' (Anonymous I669, pp. 4-5). Unmistakably, the author here addresses Philipps's concerns about tradesmen and merchants 'who live upon credit, diligence and industry' (Philipps I662, p. 60). The author responds to Philipps's concerns in social and moral terms, specifically, in terms of trust, honesty and reputation, commonplace referents in seventeenthcentury discussions of the English economy (Muldrew I998; Ito 201 I; Wennerlind 20 I I, chapter 3). Thus, the 'advantage' of a register is

That by this way there shall a new Stock be brought up in the Nation to trade upon, when the Moneys at present are drained low, to wit, the Stock of Honesty; for when all mens conditions shall lye open, the trust that a man hath for the future shall be on this Honesty, and not on a deceitful Reputation of more than he is worth[.] (Anonymous I669, p. 5)

In the author's view, the 'honesty' that a registry would produce offers a solution to the other problem Philipps foresaw, that no one would lend to industrious and hopeful young men without sufficient property. ${ }^{26}$ Honesty, the author hopefully asserted, 'shall put it in the power of every man to have at first wherewithal to live

26 Smail (2005) shows that the concept 'honour' played an important role in the credit network of the eighteenth century. 
upon'. Thus, a registry would be not an impediment but a 'Publick Encouragment to the industrious beginner, and hopeful man'. At the end of the pamphlet, having dispatched Philipps's arguments, the author called directly for the reform of registration (Anonymous I669, pp. 5, 7-8).

Philipps's rebuttal, in the form of a pamphlet entitled The Pretended PerspectiveGlass, which, as the subtitle presents, was 'offered against the pretended registring reformation, was published in the same year as A Seasonable Proposal. Philipps's argument against registration was simple: 'Innovations are more than a little dangerous'. This cautious stance brings to mind the preface of the I67I version of The Reforming Registry, discussed below.

In this period, Dutch trade was at its 'zenith', the 'Anglo-Dutch conflict was at its height' (Israel I989, p. 279), and the English economy was unstable. Philipps's caution about his country's economy reflects his sense of its fragility, which may have been rooted in the second Anglo-Dutch war and the resulting 'decay of trade'. Philipps argues that wars, plunderings, sequestrations and taxes have so 'universally indebted' the people of England that most 'live more upon Credit' than their own possessions, and therefore, that their survival is deeply dependent on credit (Philipps I669, pp. I-2). Given this dependency, the negative effects on credit of the newly contrived 'innovation', that is, registration, and the excessive disclosure of information it precipitated, would be disastrous for every social group in the country: the nobility and gentry would 'be turned out of that Credit' in the exposure of their 'languishing Estates'; merchants and detailers whose businesses heavily relied on credit would lose their credit 'when they shall be exposed to the jealous eyes of the nice, over-timerous and Usurers or Money-lenders'; and it would be the same for country farmers without sufficient stock or property 'to endure the severity of a Telltale Registration' (Philipps I669, pp. 2-3). This class-byclass analysis led Philipps to conclude that with the introduction of registration, 'All Trust and Credit, and the Faith, Charity and Love of Mankind one to another ... will be so enervated and weakened' as to make people 'like crafty Banyans, and hard hearted Jews each to other.' The worry of the 'Broken-Tradesman' in A Seasonable proposal was here enhanced. Moreover, the disaster would extend to national security: the 'Contrivance' of registration would expose the state of the national economy in detail for all to see, enabling 'Foreign Princes' to 'discover the weaknesse of the Nation' (Philipps I669, pp. 3-4).

Perhaps surprisingly from our viewpoint, however, Philipps concluded by recommending the establishment of a bank of charity, an approach which had already been 'successfully practised in many parts beyond the Seas, to relieve the people in their debts and oppression, increased by an unchristian-like Usury and Brocage', as more effective than setting up a registry. Given that a 'Mont Pietes', that is, a bank of charity, was widely viewed as a desirable means of providing institutional credit at the time,${ }^{27}$ Philipps may have seen banks of charity and registration as competing approaches to providing credit; of the two, the former seemed better to him than

27 For discussion of proposals for banks of charity in this period, see Ito (20 I I, pp. 494-503). 
the latter. In closing, he reiterates his view that 'the Registring Reformers' were just out 'to ruine or perplex the people' (Philipps I669, p. I3).

The debate between Philipps and the reformers continued relentlessly, with the next shot fired by Nicholas Phillpott in his pamphlet, Reasons \& Proposalls for a Registry or Remembrancer of all Deeds and Incumbrances of Real ESTATes (I67I). In the long subtitle of this pamphlet, Phillpott tells his readers that a registry is 'to be had in every county, most necessary and advantageous as well for sellers and borrowers as purchasers and lenders: to the advance of credit and the general good'. Credit comes to the fore as a main issue for Phillpott, though his argument clearly is a response to Philipps both in that it employs his vocabulary and addresses his concerns.

Despite the 'most excellent Law' of 27 Elizabeth (I 585), which was enacted 'against fraudulent Conveyances' and 'to remedy' them, Phillpott argues that 'fraud and deceipt' were continually increasing. The course of action he advocated, however, was entirely the reverse of Philipps's; Phillpott argued for the establishment of 'a publick Registry' in each county. With such registries, according to Phillpott, 'all mischiefs and inconveniences' would be prevented. Phillpott asserts that most mischief follows from 'precedent and concealed Incumbrances', which lead to lawsuits (Phillpott I67I, pp. I-2). In the social and personal nexus of credit, such an uneasy and fragile situation of economic transactions as that observed by Phillpott would unavoidably yield widespread difficulties. An economy thus filled with scepticism demanded not just security, which in those days was more or less required when borrowing money, but 'too unreasonable securities', as Phillpott puts it, 'which enforces men to engage their friends, as well as their lands, to satisfy scrupulous lenders'. A registry would remedy this state of affairs by making it possible to grant credit without requiring such 'unreasonable' security. If a registry were established, the 'discovery' of encumbrances that it enabled would bring benefits and safety to purchasers, sellers, borrowers and lenders (Phillpott I67I, pp. 2-3).

For Phillpott, as for Philipps, and to an even greater degree for the author of $A$ Seasonable Proposal, the obscurity of land titles was a principal reason for the rising number of lawsuits. Phillpott argues, '[w]hen an Estate is once involved in unfathomed Incumbrances, then it creates suits upon suits'. Interestingly, the central issue here shifts from the relatively technical inconveniences with which Philipps and the law reformers of the Interregnum were concerned, to socio-moral factors such as reputation, and the security which would create confidence, as a basis for credit. He writes, '[i]f a person reputed to be indebted or engaged, offers land to sell, noe will adventure to deal for feare of precedent Incumbrances unles it be upon very great advantages of an vnder value (in regard of the danger)', that is, without being subject to high interest or usury. However, the condition that he viewed as most essential to making credit available was security. Phillpott clearly concludes that money-lending is a matter of social reliability, and that this might be improved by 'good security': '[t]he difficulty to borrow money proceeds not from it's scarcity, but the diffidence of good security'. In Phillpott's view, it is 'generally known' that those who have estates can easily borrow 'what they please on easie 
tearms' (Phillpott I67I, pp. 4-5). The confidence of lenders, created by 'good security', therefore ends up lowering interest rates, for Phillpott. ${ }^{28}$

Returning the discussion once again to the legal realm, Fabian Philipps brought forth an extended version of his pamphlet, The Reforming Registry, in I67I. This new edition included the main body of the original version of I662, with some editorial corrections and the chapter titles removed, as well as a 62-page preface 'to the reader' and about 250 new pages of content. In the new, long, preface, Philipps quotes from or refers to Thomas Aquinas, Cajus Cassius, Solomon, Solon, Augustus Caesar, Cato, Thucidides and Bodin in insisting that laws should not be easily changed, and that unnecessary changes to the law 'will be to vex and course the people out of their old and well approved Laws and Customs' (Philipps i67I, 'To the reader' [p. I I]). However, in this preface, the discourse in which Philipps sets his arguments on the legal context of registration originated in the law reform discussions that preceded the Restoration, which included Charles George Cock, Hugh Peters, William Sheppard and J. V. (Philipps I67I, 'To the reader' [pp. I 8, 20, 49-50, 54-5]).

However, as an English pamphleteer in the latter half of the seventeenth century when the United Provinces, particularly Holland, offered the most appealing tradenation model for England to emulate - Philipps could not avoid mentioning that Holland retained 'Publick Notaries' who were 'anciently constituted and sworn to make the peoples Contracts and Instrumenta Authenticata in their due Forms, keep Protocols or Records thereof. This weighed against Philipps's argument, of course, but he added a defensive note: 'they are not forced to go unto the Publick Notaries to make their Bonds or Writings Notarial' (Philipps I67I, pp. 94-5). ${ }^{29}$

Philipps uses the example of Spain to make clear the difficulties accompanying the use of 'Publick Notaries'. The case of Spain showed even more clearly how such systems led to disastrous results; the country was known by the 'severity and power of the Spanish Creditors upon the Debtors.' The poor, who had the weakest reputations to borrow against, were the greatest victims: the poor in Spain 'have so little Faith or Credit one with another, as not to be able to borrow any money without such a dire and prejudicial Security' (Philipps I67I, pp. I I3-I4).

A more salient argument in Philipps's revised pamphlet is his thorough analysis of registration in Scotland. Like Sir John Nisbet, Philipps found the Scottish example worthy of careful examination, though he comes to very different conclusions from Nisbet, who advocated the adoption of the land registration system of Scotland in England, as we have seen. Extending the historical and sociological explanation of Scottish society that he offers in The Pretended Perspective-Glass, Philipps

28 In the debates over interest rates from around I 668 to I 669, registration was considered as an alternative to the reduction of interest rates as a remedy for the ills of the English economy. See Anonymous (I668); Child (I668); H.R. (I668); Manley (i669).

29 Brooks, Helmholz and Stein (I99I, chapters I, 2, 3 and 4) demonstrate that public notaries in England, though less reliable and less widely used than on the Continent, existed and played some role in legal procedures from the fourteenth century onwards. 
demonstrates in The Reforming registry of I67 I a wide-ranging perspective on Scottish registration. Drawing on Sir Thomas Craig's Jus feudale, tribus libris comprehensum (I655) in particular, Philipps presents the historical background of 'Scotish Registring' and shows how it became unreliable and ineffective. Due to 'a jealousie upon all private Deeds or Writings', Philipps explains, 'Publick Notaries' had been 'instituted' in Scotland since the Roman-empire period, because 'many men made it their studies or business to counterfeit hands and writings'. These public notaries became the agents of 'Scotish Registring'. However, just as notaries were instituted to stop 'the abuse of private writings', so 'by the fraud and wickedness of Notaries, the private writings came again to be of use'. People ended up giving 'no credit to Notarial Writings ..., though the Notary affirm it' (Philipps I67 I, pp. I I 8-i9). The Scottish example, in Philipps's argument, thus served as evidence of the perniciousness of registration.

Following the debate between Philipps and the reformers that transpired around I670, there was little discussion of registration and credit, either in print or in parliament, until pamphleteers revived the subject as a central concern at the time of the Exclusion Bill Crisis. Mark Lewis and Dr Hugh Chamberlen, two of the most active bank proposers in this period, provided the context for this renewed debate. ${ }^{30}$ For both, land offered the best form of security for banks. In other words, they proposed land banks, if only ones that resembled Lombard banks loaning money on pawn. For bank proposers such as Lewis, as the quotation at the beginning of this study makes clear, registration was essential for land bank projects to improve the quality of their security. ${ }^{31}$

Against the backdrop of such proposals, Andrew Yarranton, an 'unsuccessful' river engineer $(O D N B)$, published his own voluminous proposal entitled England's Improvement by Sea and Land in I677. In the subtitle of this book, Yarranton presents his basic arguments and views on the issues of previous debates concerning registration, such as the prevention of lawsuits and other benefits, in the framework of England's rivalry with Holland: 'To out-do the Dutch without fighting, to pay debts without moneys, to set at work all the poor of England with the growth of our own lands. To prevent unnecessary suits in law; with the benefit of a voluntary register.' While the growing power of France posed the great danger of 'breaking the Balance of Europe', and hence represented a serious threat to England in Yarranton's view, Holland was in an ambivalent position. It was a menace for England, on the one hand, and a model to follow and imitate, on the other. ${ }^{32}$ Based on what was 'already experienced

30 See Lewis (I677a; I677b; I678; [I678]; n.d.); [Chamberlen] [I682]; Chamberlen and Murray (I682).

31 Concerning the bank projects around I680, see Horsefield (I960, chapters 9 and Io); Ito (20 I I, pp. 504-I4).

32 Concerning the complex relationship between England and Holland during the first and second Anglo-Dutch wars, see Pincus (I996). On the political situation in the time of the Exclusion Crisis, see Knights (I994, p. 362). Ormrod (2003) illustrates the rivalry of the two countries. 
in Neighbour Nations', Yarranton tried to show that while England could not beat the Dutch 'with fighting', it might be able to do so 'without fighting', that is, by putting the lands of England under a Voluntary Register by Act of Parliament' (Yarranton I677, pp. bb2, c).

For Yarranton, a prerequisite for the trade that would produce this success was the quality of honesty, which Phillpott too recognised as important for smooth economic transactions. ${ }^{33}$ Yarranton argues that for

All Kingdoms and Common-wealths in the World that depend upon Trades, common Honesty is as necessary and needful in them, as Discipline is in an Army, and where is want of common Honesty in a Kingdom or Commonwealth, from thence Trade shall depart. For as the Honesty of all Governments is, so shall be their Riches; And as their Honour, Honesty, and Riches are, so will be their Strength; And as their Honour, Honesty, Riches, and Strength are, so will be their Trade.

Honour, honesty, riches, strength and trade are thus causally related for Yarranton; they are 'five Sisters that go hand in hand, and must not be parted'. This relationship recurs as a basic principle throughout the book. For instance, in enumerating another set of five advantages that Holland enjoyed - the settlement of a public register, 'Communicable and Easie' trade by making rivers navigable, a public bank, a court of merchants, and a 'Lumber-house' (Yarranton I677, pp. 6-7) - Yarranton attributes these achievements of the Dutch to the 'five Sisters'.

In Holland, Yarranton predicted, registration would continue to produce benefits: '[a] Register will quicken Trade, and the Land Registred will be equal as Cash in a mans hands, and the Credit thereof will go and do in Trade what Ready Moneys now doth'. In brief, registration would provide the security on which credit ultimately relies. It was a mistake, in Yarranton's view, to think that 'a great Cash in Bank' was the driving force of the Dutch prosperity. Rather, he argued that it was what lay behind the paper credit of their banks, namely, 'the Anchorage, Fund and Foundation' of their lands. Critically, these lands were 'laid Safe ... under a Register, from whence issue these delightful Golden Streams of Banks, Lumberhouse, Honour, Honesty, Riches, Strength and Trade'. If a bank holding such 'a good, secure, and unperishable foundation' were established in England, Yarranton promised, money would be 'tumbled' at low interest rates there as in Holland. Taking the city of Salisbury as an example, Yarranton argued that English cities needed only the authority of the law to register all their houses and lands, and that the 'Anchorage and Foundation' backed by this authority would make their trade 'comfortable' (Yarranton I677, pp. I2, I3, 23, 29).

Whether registration should be voluntary or not, and whether it should be established only in London or in each region - key questions in discussions of registration

33 Yarranton refers as follows to 'Nicholas Phillpot of Hereford': 'in the next County an Attorney (Nicholas Phillpot of Hereford) about four years since put out in print two sheets, to shew Reasons wherefore a Rigister of Lands is needful' (Yarranton I677, p. I0). It is not certain whether these 'two sheets' refer to Phillpott's pamphlet of I67I or other writings. 
since the law reform debates of the Interregnum - were central questions for Yarranton as well. If London and other cities and regions in England, such as Middlesex, Essex, Kent, Surrey, Yorkshire and Lincolnshire, were under voluntary registers, Yarranton argued, 'then there would be as great a Bank at London as at Amsterdam, and wold be able to do much more in Trade, Credit, and all great things, than they can'. While Philipps condemned registration in Scotland, Yarranton praised it, emphasising the superiority of Scotland's dual registration system over a single, centralised one: with 'a Grand Register' at Edinburgh and a register in each county, nobody would be deceived in a purchase (Yarranton I677, pp. I6, 28).

Yarranton anticipated a group of 'hard Questions' of a practical and technical cast that his proposal for registration would raise: the questions, first, of who keeps the register; second, of who chooses him; third, of how he is to be chosen; fourth, of who pays him; and finally, on what 'Security' he is to rely 'to perform his Trust' (Yarranton I677, p. 33). The answers that Yarranton provided to these questions were, of course, administrative, but had a notably ethical tenor as well that followed from the precept that registers were to be places that as far as possible instituted 'Honesty and Honour'. Hence, Yarranton's explanation offers procedural details for ensuring the 'Honesty and Honour' of the register:

[a]s to the First, let the Register be kept by two Gentlemen whom you have experience of for Honour and Honestie. Secondly, let the Register be chosen by the Major voyces of all the Freeholders in and within ten Miles of the City of Sailsbury, who have forty shillings a year and upwards. Thirdly, Let him be chosen by the way of the Baletting Box ... And certainly this way would drive out base interests and prefer men of Honesty and Honour. To the Fourth, ... be ought to have it out of the Lands Registred; but have a care of allowing too much. And as to the Fifth, ... get as honest and as rich a man as you can, then the slenderer Security will serve. (Yarranton I677, pp. 33-4)

'Honesty and Honour' here function vitally to maintain the proposed administrative system. For Yarranton, these values are the most essential factors in the design of the project. Yarranton's concern with the practical and technical specifics of his proposed register parallels the enthusiasm for administrative details reflected in Mark Lewis's bank proposals, in which Lewis describes not only staff positions that would be required in the proposed office, such as masters and assistants, but their salaries as well (Lewis I678, pp. I3, 7). Yet Yarranton's development of his interests around his precepts of 'Honesty and Honour' amounts to a significant departure from his bank-proposing contemporary.

Yarranton's plan for corn granaries exemplifies the original reasoning that follows from his 'Maxim' that 'Honour and Honesty bring Riches'. For Yarranton, granaries would serve the same function as banks, including that of anchoring credit. By sending his corn into 'the Publick Bank-Granary, and there lodging it', a tenant could give his landlord 'Bank-Credit in Corn for his Rent'. Through the registration of the tenant's corn at the guildhall in London, 'good credit' would be created that would 'inliven Trade, and fetch out all Moneys now unimploy'd' (Yarranton I677, 
pp. I22-3, I26, I27). A register here serves as the foundation of a practical mechanism for realising his 'Maxim'.

In considering 'the Publick Granary', Yarranton presents the credit it would facilitate as analogous to money. Corn deposited in the granary would be registred in a 'Register Book', whereupon the owner of the corn would take 'a Note under the Hand and Seal' of the 'Granary-Register' documenting the quantity of corn deposited, the time of delivery, and the kind of corn. This 'Ticket' from the Granary-Register could be transferred by the owner, and thus offered a means of addressing 'want of present Moneys' and 'want of Credit'. Money had often been likened rhetorically to blood in the human body; Yarranton here replaces it in this conventional comparison with corn: 'it will be, if done, as the Blood in the Body, it will so circulate in a few years, that Corn will be to England better than ready Moneys.' Corn registred in the 'Publick Granary' would function as money, Yarranton proposed, resolving all problems which arise from want of money, just as credit would do. Yarranton thus clearly argued that 'Lands Registred' and 'Bank-Corn' would function as bases for credit. Yarranton is in agreement with most bank proposers of the seventeenth century in insisting that the credit they hoped to foster would be equal or even superior to money; as Yarranton put it, 'the Land Registred, will do what Money now doth; and this is credit equal to Moneys'; or more simply, 'Corn in Bank is Money in Purse, nay better' (Yarranton I677, pp. I3 I-2, I38, I42, I66). Such credit, Yarranton emphasised, could function effectively only in a system incorporating registers, for registers were needed at the base of all systems of credit as an 'undeniable' foundation.

Hence, Yarranton argued that one of the reasons for the decay of trade in London was 'the Neglect of putting Houses to be new built under a Register'. In Yarranton's view, registers integrated with institutions of credit and trade would have prevented a persistent, deeply embedded problem from taking root in the early modern English economy, that is, the misery caused by the vicious pawn-broking business: 'by virtue of such undeniable Security as Registred Houses, Banks (yea many just Banks ) and Lumber Houses would have sprang up, which had so enliven'd Trade, and preserved the Poor out of the hands of the Usurers, and pawn-Brokers'. Yarranton here joins many others in condemning pawnbrokers for abusing the poor, and claims moreover that his project would 'unavoidably ruine PawnBrokers' (Yarranton I677, pp. I76-8, I72).

\section{I}

A contemporary of Yarranton's, an anonymous 'Well-Wisher', adopted the vocabulary and framework of the arguments of Philipps and others from the debates of the previous decade, but added some new twists. In a pamphlet dated 4 February I677/8 entitled Reasons for a Registry, ${ }^{34}$ 'Well-Wisher' tried to demonstrate how registration

34 The British Library holds a manuscript entitled 'Reasons for a Registry', which is an almost perfect hand-written transcription of Well-Wisher's Reasons for a Registry (Anonymous, c. I 70o). 
and the issues upon which it bore - legal matters in the discourse of the Interregnum and later economic issues in land bank proposals - are all interrelated. 'Well-Wisher's' analysis may be summarised in brief as follows: trade depends on the money-lending business, which depends on a secure fund, which depends on land as security, and this requires a registry; in 'Well-Wisher's argument', registration thus turns out to support trade (Anonymous I678a, pp. -3--2).

A reduction in the interest rate was one of three trade promotion measures proposed in the House of Lords, as we have seen. However, this approach too would prove ineffective, 'Well-Wisher' argues, because it does not provide 'a certain security' to lend money. Here the author again asserts that trade and commerce will not benefit from such measures 'without establishing such security'. It is therefore necessary first 'to discover such a convenient medium for a Fund, or security as may properly reconcile the difficulties already premised'. The author's insistence on an assured and dependable form of security was widely shared in the bank-proposals of the time. Although the basis of such funds was a matter of serious debate, ${ }^{35}$ 'Well-Wisher's' plan also shared with the so-called land bank projects the argument that land offered the best security or fund (Anonymous I678a, p. 7).

'Well-Wisher' next considered the question of how best to secure such 'certain' funds of land. His answer is what he calls 'a short Model' of registration. His plan centres on a law that would require all who hold titles or encumbrances to register them. The author clearly based this 'model' of registration on the preceding discussions of more than two decades. Moreover, the author anticipated the same 'prejudices' raised by the pamphleteers who had opposed registration in these debates. The 'great prejudices' foreseen by 'Well-Wisher' were commonly mentioned ones in this discourse: the exposure of 'the private concerns of one Mans Estate; losing reputation as its result; the cases of infants, foreigners, and people without 'Evidences' (Anonymous I678a, pp. 9-i9).

However, beyond these particular problems that might arise from registration, 'Well-Wisher' also addressed the general doubts accompanying any innovation (Anonymous I678a, p. I9), a subject often discussed in bank proposals of the period. While more than a decade later John Briscoe in his land bank proposal, quoting Descartes, would be troubled by the persistency of custom as 'a second Nature' (Briscoe I694, p. 2I), 'Well-Wisher' worried about the 'forward retention of Custom', quoting the following from Francis Bacon's essay 'On Innovations':

It is true that what is settled by Custom, though it be not good, yet at least it is fit; and whose things which have long gone together, are as it were Confederate among themselves; whereas new things piece not so well; and though they help by their utility, yet they trouble by their inconformity[.] (Anonymous I678a, p. 20) (36 $^{36}$

35 See Horsefield (I960, chapter Io); Ito (20 I I).

36 These sentences are quoted from Francis Bacon's Essays. See Bacon (I995, p. 65). 
Nevertheless, even though he admitted all these potential disadvantages of registration, 'Well-Wisher' was confident that it would be beneficial for people of every sort. New remedies against 'fraudulent practices and contrivances', in short, were needed (Anonymous I678a, p. 22). Registration was one such remedy.

Another anonymous pamphlet, entitled Reasons against a Registry for Lands, rebuts 'Well-Wisher's' proposal for a registry point by point, insisting on the inadvisability of registration: the present is no time for introducing 'such a strange, unusual and dangerous Remedy'. Suspicion of the 'security' of the proposed registry, above all, permeates Reasons against a Registry. The author's doubts about the security of registration may seem technical; for instance, he notes that it would be easy to 'frame two Deeds' for one estate. At the heart of the argument, however, the author argues that given people's lack of morality, a registry would eventually 'capacitate ill Husbands in the Country to borrow Money to waste extravagantly' and multiply the uncertainty of trade (Anonymous I678b, pp. 2-3, I2-I 5).

Where Reasons for a Registry argues for the benefits and necessity of the 'Innovation', Reasons against a Registry emphasises that registration would make English property laws 'shake, and disturb the peace and quiet of of [sic] many thousands of sober and well-minded people throughout the Kindom [sic]'. Registration was not 'a new Medicine for a new Disease' but 'a Venomous Medicine' which would surely lead to 'an universal indisposition of the whole Body' (Anonymous I678b, pp. I6-I7).

In the closing paragraphs of Reasons against a Registry, the author argues that there would be no 'security' in a registry unless deeds and encumbrances were registered in their entirety. This argument serves to introduce a proposal 'to establish in every Market Town in England, a Registry for all personal Contracts' (Anonymous I678b, pp. I2, I7). The author presents this novel registry as offering two types of advantage: 'conveniencies' and reliability. Among the 'conveniencies' that it would afford, the author was particularly confident of a reduction in the number of lawsuits. The second advantage, enhancing the reliability and safety of economic transactions, was a matter of great interest at that time. The selection of officers to conduct business, for instance, was a subject of debate in the bank projects of this period, as we have seen in the proposals of Lewis and Yarranton, and it was considered central to the reliability of a given project. The author thus suggests that ' $[\mathrm{t}]$ he Register himself and his Deputy, may be elected by the Inhabitants of the Town, where such Registry is to be kept, and ought to be persons inhabiting there, and of known integrity' (Anonymous I678b, pp. I7-I9). Ultimately, the author's position in the controversy is thus 'for' registration itself, though he is against 'a Voluntary Registry'. He argues for a system of total registration, and for the establishment of a registry in each county or town.

\section{VII}

Every facet of English society was in transition during the early modern period. New ideas, whether political, institutional, or economic, were caught in the tensions 
between the traditions of the past and the unfamiliar landscape of tomorrow. The fields of law and trade, as the history of registration makes clear, were typical examples in this regard. ${ }^{37}$ The controversy over land bank projects in the I690s reflected the uncertainty of a changing society, an early phase in the centuries-long effort to establish a safe and reliable credit system. Since Horsefield's British Monetary Experiments, economic historians have been aware of the debate between proponents of the Bank of England and land bank proposers on the establishment of credit institutions in the last decade of the seventeenth century. ${ }^{38}$ Rubini (I970), Carruthers (I999, pp. I4I-2), Pincus (2009, pp. 388-96) and Pincus and Wolfram (20II) describe this debate in the partisan frame of whig versus tory. However, the discourse on registration and credit which I have here traced may shed a different light on the discussion which occurred after the Glorious Revolution. While the coming debates would be illustrated with more distinctly economic and political colours, I have shown that their pre-history was constructed in legal and moral contexts.

In particular, I have demonstrated that the very idea of land banks originated in the lengthy preceding discourse on credit and registration of land, which centred on issues and vocabulary that emerged from the law reform debates of the Interregnum. These often concerned legal matters, such as the potential for increasing the number of lawsuits or excessive exposure of private information, both of which were feared as consequences of upsetting the order of a fragile society. In this context, precursors of the land bank proposers, prior to the Glorious Revolution, chose land to serve as the security, or fund, of banks. The necessity of some system to make land the most reliable security had long been recognised, and the registration of lands was the system upon which debate centred. Throughout the century, the establishment of a registry or registries remained an important issue in economic discussions, and registration of estates was proposed often, usually as a measure to improve the safety of economic transactions. The registration of land was envisioned as an institution to fortify credit, which hitherto had been considered quite fragile.

Submitted: I9 November 20 I I

Revised version submitted: I2 February 2013

Accepted: I3 March 2013

First published online: I4 May 2013

\section{References}

ANONYMOUS (n.d.). Proposals Concerning County Registers. In The Hartlib Papers.

ANONYMOUS (I649). The Representative of Divers Well-affected Persons in and about the City of London Touching the Present Laws and Government. London.

37 In extensively researched studies, Brooks (2008) and Grassby (I995) demonstrate such slow and halting transitional processes in the fields of, respectively, law and business.

38 According to Murphy (I997, chapter 6), the land-bank proposal of John Law was an extension of the discussion between Hugh Chamberlen, John Briscoe and John Asgill. 
ANONYMOUS [1650]. Several Proposalls Tendered to the Consideration of the Honorable Committee for Regulating of Courts of Justice, for a Thorough Reformation Thereof, etc. [London].

ANONYMOUS (1653). Reasons against the Bill, Intituled, An Act for Countie-Registers, Wills and Administrations. London.

ANONYMOUS (1659a). Chaos, or, a Discourse wherein is Presented to the View of the Magistrate. London.

ANONYMOUS (I659b). The Honest Design: or, the True Commonwealthsman. London.

ANONYMOUS (I668). Interest of Money Mistaken. London.

ANONYMOUS (I669). A Seasonable Proposal to the Nation concerning a Register of Estates in this Kingdom.

[London].

ANONYMOUS (I678a). Reasons for a Registry. London.

ANONYMOUS (I678b). Reasons against a Registry for Lands. London.

ANONYMOUS (c. I700). Reasons for a Registry. British Library [Henceforth BL] MSS Add28092, fos. IO6-27.

BACON, F. (1995). Essays . New York: Prometheus Books.

BILling, E. (I659). A Mite of Affection, Manifested in 31 Proposals. London.

BRENNER, R. (I993). Merchants and Revolution: Commercial Change, Ppolitical Conflict, and London's Overseas Traders, 1550-1653. Princeton: Princeton University Press.

BRISCOE, J. (1694). An Explanatory Dialogue of a Late Treatise, Intituled, a Discourse on the Late Funds of the Million-act, Lottery-act, and Bank of England. London.

BROOKS, C. W. (2008). Law, Politics and Society in Early Modern England. Cambridge: Cambridge University Press.

BROOKS, C., Helmholz, R. H. and STEIN, P. (I99I). Notaries Public in England since the Reformation. Norwich: Erskine Press.

CARLOS, A. M. and NEAL, L. (2OI I). Amsterdam and London as financial centers in the eighteenth century. Financial History Review, I8(I), pp. $2 \mathrm{I}-46$.

CARruthers, B. G. (I999). City of Capital: Politics and Markets in the English Financial Revolution. Princeton: Princeton University Press.

[CHAMBERLEN, H.] [i682]. Several Objections Sometimes Made against the Office of Credit, Fully Answered. [London].

CHAMBERlen, H. and MURRAY, R. (I682). Articles of Agreement between the Mayor and Court of Common Council [of London], Dr. Chamberlen and Mr. Murray. London Metropolitan Archives, $\mathrm{COL} / \mathrm{SJ} / 27 / 6$ I 8 , fo. I.

CHILD, Sir J. (I668). Brief Observations concerning Trade and Interest of Money. London.

COLE, W. (I659). A Rod for the Lawyers. London.

COTTERELL, M. (1968). Law reform: the Hale commission of I652. The English Historical Review, 83, pp. $689-704$.

CRADOCK, F. (I66I). Wealth Discovered. London.

CROMARTIE, A. (1995). Sir Matthew Hale, 1609-1675, Law Religion and Natural Philosophy. Cambridge: Cambridge University Press.

GARNIER, R. M. (1908 [1892-3]). History of the English Landed Interest: Its Customs Laws and Agriculture. New York: Macmillan.

GASKILL, M. (2000). Crime and Mentalities in Early Modern England, Cambridge: Cambridge University Press.

GLAISYER, N. (2006). The Culture of Commerce in England, 1660-1720. Woodbridge: Boydell Press.

GRASSBY, R. (1995). The Business Community of Seventeenth-Century England. Cambridge: Cambridge University Press.

HALE, Sir M. (1694). A Treatise Shewing how Usefull, Safe, Reasonable, and Beneficial the Inrolling \& Registring of all Conveyances of Lands May Be to the Inhabitants of this Kingdom. London.

HECKSCHER, E. F. (I935 [I93 I]). Mercantilism, trans. M. Shapiro, vols. I-2. London: Allen \& Unwin.

HILL, L. M. (2007). 'Extreme detriment': failed credit and the narration of indebtedness in the Jacobean Court of Requests. In E. Sharp and M. C. Fissel (eds.), Law and Authority in Early Modern England. Newark: University of Delaware Press.

HOPPIT, J. (2003). The landed interest and the national interest, I660-I800. In J. Hoppit (ed.), Parliaments, Nations and Identities in Britain and Ireland, 1660-1850. Manchester: Manchester University Press.

HORSEFIELD, J. K. (1960). British Monetary Experiments 1650-1710. London: G. Bell and Sons Ltd. 
H.R. (I668). The Brief Observations of J. C. concerning Trade and Interest of Money Briefly Examined by H. R. [London].

HUNTER, M. (I98I). Science and Society in Restoration England. Cambridge: Cambridge University Press.

HUNTER, M. (I989). Establishing the New Science. Woodbridge: Boydell Press.

ISRAEL, J. I. (I989). Dutch Primacy in World Trade, 1585-1740. Oxford: Oxford University Press.

ITO, S. (20 I I). The making of institutional credit in England, I600-I688. European Journal of the History of Economic Thought, I8(3), pp. 487-519.

J. F. (I653). The Laws Discovery. London.

J.W. (I653). A Mite to the Treasury of Consideration in the Common-wealth. London.

KERRIDGE, E. (I988). Trade \& Banking in Early Modern England. Manchester: Manchester University Press.

KLEER, R. A. (2004). 'The ruine of their Diana': Lowndes, Locke, and the Bankers. History of Political Economy, 36(3), pp. 533-56.

KNIGHTS, M. (I994). Politics and Opinion in the Exclusion Crisis, 1678-81. Cambridge: Cambridge University Press.

LEACH, W. (I65I). Propositions. [London].

LENG, T. (2005). Commercial conflict and regulation in the discourse of trade in seventeenth century England. The Historical Journal, 48(4), pp. 933-54.

LENG, T. (2008). Benjamin Worsley (1618-1677): Trade, Interest and the Spirit in Revolutionary England. Woodbridge: Boydell Press.

LEWIS, M. (n.d.). A Model of a Bank. BL MSS Add28079, fo. I48.

LEWIS, M. (I677a). Proposal to the King and Parliament, how this Tax of One Hundred Sixty Thousand Pounds per Moneth, May be Raised. London.

LEWIS, M. (I677b). Proposals to Increase Trade and to Advance his Majesties Revenue. London.

LEWIS, M. (I678). Proposals to the King and Parliament, or, a Large Model of a Bank. London.

LEWIS, M. [1678]. A Short Model of a Bank. London.

MANLEY, T. (I669). Usury at Six Per Cent. Examined. London.

MATTHEWS, N. L. (I984). William Sheppard, Cromwell's Law Reformer. Cambridge: Cambridge University Press.

MCCORMICK, T. (2009). William Petty and the Ambitions of Political Arithmetic. Oxford: Oxford University Press.

MCGOWEN, R. (2002). Credit and culture in early modern England. Journal of British Studies, 4I(I), pp. I $20-3 \mathrm{I}$.

MULDREW, C. (I998). The Economy of Obligation. Basingstoke: Macmillan.

MURPHY, A. E. (1997). John Law: Economic Theorist and Policy-Maker. Oxford: Clarendon Press.

NEAL, L. (1990). The Rise of Financial Capitalism: International Capital Markets in the Age of Reason. Cambridge: Cambridge University Press.

NISBET OF DIRLETON, Sir J. [1669]. On land registration. BL MSS Add23 I 32.

ORMROD, D. (2003). The Rise of Commercial Empires: England and the Netherlands in the Age of Mercantilism, 1650-1770. Cambridge: Cambridge University Press.

PETERS, H. [i647]. A Word for the Armie. [London].

P[ETERS], H. (I65I). Good Work for a Good Magistrate, or, a Short Cut to Great Quiet, by Honest ... Hints Given ... for the Regulating of Most Cases in this Commonwealth, concerning Religion, Mercie, Justice. [London].

PETTY, W. (i 899). The Economic Writings of Sir William Petty, ed. C. Hull. Cambridge: Cambridge University Press.

PETTY, W. (I927). The Petty Papers, ed. Marquis of Lansdowne, 2 vols. London: Houghton Mifflin Co. PHILIPPS, F. (I662). The Reforming Registry. London.

PHILIPPE [= PHILIPPS], F. (I665). An Expedient to Prevent the Fraudes and Deceites in the King's Eustomes. BL, Add28079.

PHILIPPS, F. (i 669). The Pretended Perspective-Glass. London.

PHILIPPS, F. (I67I). The Reforming Registry. London.

PHILlPOTT, N. (I67I). Reasons E Proposalls for a Registry. Oxford. 
PINCUS, S. C. A. (1996). Protestantism and Patriotism: Ideologies and the Making of English Foreign Policy, 1650-1668. Cambridge: Cambridge University Press.

PINCUS, S. C. A. (2009). 1688: The First Modern Revolution. New Haven; London: Yale University Press.

PINCUS, P. and WOLFRAM, A. (20II). A proactive state? The land bank, investment and party politics in the I690s. In P. Gauci (ed.), Regulating the British Economy, 1660-1850. Farnham: Ashgate.

POCOCK, J. G. A. (I987 [I957]). The Ancient Constitution and the Feudal Law: A Study of English Historical Thought in the Seventeenth Century. Cambridge: Cambridge University Press.

RICHARD, R. D. (I965 [I929]). The Early History of Banking in England. London: Frank Cass \& Co Ltd.

ROBINSON, H. (I65I). Certain Considerations in Order to a More Speedy, Cheap, and Equall Distribution of Justice throughout the Nation. London.

ROBINSON, H. (I652). Certain Proposals in Order to the Peoples Freedome and Accommodation in Some Particulars. London.

RUBINI, D. (I970). Politics and the battle for the banks, I688-i697. English Historical Review, 85, pp. 693-7I4.

SHAPIRO, B. (I975). Law reform in seventeenth century England. The American Journal of Legal History, I9(4), pp. 280-3 I2.

SHEPPARD, F. and BELCHER, V. (I980). The deeds registries of Yorkshire and Middlesex. Journal of the Society of Archivists, 6, pp. 274-86.

SHEPPARD, W. (I657). Englands Balme. London.

SLACK, P. (I998). From Reformation to Improvement: Public Welfare in Early Modern England. Oxford: Clarendon Press.

SMAIL, J. (2005). Credit, risk, and honor in eighteenth-century commerce. Journal of British Studies, 44, pp. $439-56$.

SPRIGG, W. (1659). A Modest Plea for an Equal Common-wealth against Monarchy. London.

SUPPLE, B. E. (I957). Currency and commerce in the early seventeenth century. Economic History Review, I0, pp. 239-55.

THIRSK, J. (I992). The Crown as projector on its own estates, from Elizabeth I to Charles I. In R. W. Hoyle (ed.), The Estates of the English Crown, 1558-1640. Cambridge: Cambridge University Press.

VEALL, D. (I970). The Popular Movement for Law Reform, 1640-1660. Oxford: Clarendon Press.

WENNERLIND, C. (20 I I). Casualties of Credit: The English Financial Revolution, 1620-1720. Cambridge, MA: Harvard University Press.

YARRANTON, A. (I677). England's Improvement by Sea and Land. London.

\section{Sources}

British Library MSS Add35863: Minutes of the Extra-Parliamentary Committee for Regulating the Law, Hardwicke Papers.

CSPC AWI = Calendar of State Papers Colonial, America and West Indies, vol. I: 1574-1660 (1860); vol. 5: 1661-1668 (I 880).

British Radicals $=$ R. L. Greaves and R. Zaller (eds.), Biographical Dictionary of British Radicals in the Seventeenth Century, vols. I-3. Brighton: Harvester Press, I982-4.

The Hartlib Papers, 2nd edition. Sheffield, HROnline, 2002.

CJ = Journal of the House of Commons.

$L J=$ Journal of the House of Lords.

$O D N B=$ H. C. G. Matthew and B. Harrison (eds.), Oxford Dictionary of National Biography. Oxford: Oxford University Press, 2004. 